\title{
Short communication: Effect of sampling time relative to the first daily feeding on interpretation of serum fatty acid and $\beta$-hydroxybutyrate concentrations in dairy cattle
}

\author{
G. F. Quiroz-Rocha, ${ }^{11}$ S. J. LeBlanc, † T. F. Duffield,† B. Jefferson, ${ }^{*}$ D. Wood, ${ }^{*}$ K. E. Leslie,† and R. M. Jacobs ${ }^{*}$ \\ *Department of Pathobiology, and \\ †Department of Population Medicine, University of Guelph, Ontario, Canada N1G 2W1
}

\section{ABSTRACT}

Serum nonesterified fatty acid (NEFA) and $\beta$-hydroxybutyrate (BHBA) concentrations are used to evaluate energy status in peripartum dairy cows. Blood samples from 37 cows in the week before parturition and 47 cows in the first week after parturition from 3 dairy herds were taken $1 \mathrm{~h}$ before the first feeding $(-1 \mathrm{~h})$ as well as 4 and $10 \mathrm{~h}$ after the first feeding. Nonesterified fatty acid concentrations were measured in samples from cows before calving and BHBA was measured in samples from lactating cows. Mean NEFA concentrations in the prepartum cows were significantly higher at $-1 \mathrm{~h}(0.20 \mathrm{mmol} / \mathrm{L})$ than at $4 \mathrm{~h}(0.14 \mathrm{mmol} / \mathrm{L})$, but were not different between 4 and $10 \mathrm{~h}(0.17 \mathrm{mmol} / \mathrm{L})$. Using a cutpoint of NEFA $\geq 0.4 \mathrm{mmol} / \mathrm{L}, 32 \%$ of cows had high concentrations at $-1 \mathrm{~h}$ compared with $16 \%$ of the same cows at 4 and $10 \mathrm{~h}$. There were no differences in mean BHBA between $-1 \mathrm{~h}(646 \mu \mathrm{mol} / \mathrm{L})$ and $4 \mathrm{~h}$ $(596 \mu \mathrm{mol} / \mathrm{L})$, but mean BHBA was higher at $10 \mathrm{~h}$ $(711 \mu \mathrm{mol} / \mathrm{L})$ than at $-1 \mathrm{~h}$. Using a cutpoint of BHBA $\geq 1,400 \mu \mathrm{mol} / \mathrm{L}$, there were no differences in the proportions of high BHBA, which were 9,11 , and $13 \%$ of cows at $-1,4$, and $10 \mathrm{~h}$, respectively. Prandial effects on serum NEFA may affect interpretation of this analyte. In order not to misclassify cows when assessing energy status, samples for NEFA must at least be taken at a consistent time relative to feeding within a given herd. When sampling cows to monitor elements of energy metabolism in the prepartum period, there was twice the probability of detecting animals with NEFA values $\geq 0.4 \mathrm{mmol} / \mathrm{L}$ if they were sampled $1 \mathrm{~h}$ before the first feed delivery compared with sampling the same cows 4 or $10 \mathrm{~h}$ after feeding.

Key words: fatty acid, $\beta$-hydroxybutyrate, feeding, time

Received February 17, 2009.

Accepted January 18, 2010.

${ }^{1}$ Corresponding author: gfquiroz@servidor.unam.mx
The transition period is a critical time for dairy cows during which much of the main regulation for lactation and the reproductive cycle take place (Doepel et al., 2002; Smith and Risco, 2005). Negative energy balance (NEB) occurs in early lactation as a consequence of reduced DMI and the initiation of milk production (Grummer, 1993; Cameron et al., 1998).

Measurement of selected metabolites in blood has been used to assess the energy status of dairy cows at both the individual and herd level. Nonesterified fatty acids and BHBA are readily measurable analytes that are useful in evaluation of the energy status of the transition cow (Herdt, 2000). Nonesterified fatty acids are a frequently used indicator of energy status in the precalving period (Kunz et al., 1985; Kaneene et al., 1997; Duffield, 2004). $\beta$-Hydroxybutyrate has been reported to be a better indicator of energy metabolism than NEFA in the postpartum period (Pushpakumara et al., 2003). Cows with increased NEFA in the weeks immediately before and after calving and BHBA in early lactation are at higher risk of subsequently having left displaced abomasum (LDA); however, BHBA increases only after calving (LeBlanc et al., 2005).

Biochemical analytes may undergo diurnal variation (Coggins and Field, 1978; Manston et al., 1981; Abdelkader and Ropstad, 1989; Xing et al., 1991). For example, Manston et al. (1981) identified significant variations in $\mathrm{BHBA}$, urea, $\mathrm{Ca}, \mathrm{Na}, \mathrm{Mg}$, and $\mathrm{Cu}$ over a 9-h period. However, prandial and circadian effects may be confounded under field conditions.

Eicher et al. (1999) determined variations of analytes, including BHBA and NEFA, in component-fed dairy cows that were 40 to 110 and 150 to 230 DIM, respectively. These researchers observed decreasing BHBA between 2 and $10 \mathrm{~h}$ after first feeding, as well as a tendency for fatty acid concentration to increase in the same period of time, being significantly different at $10 \mathrm{~h}$ after first feeding.

Studies (de Boer et al., 1985; Christensen et al., 1997; Brickner et al., 2007) have determined variations of NEFA and BHBA concentrations through the day and related them to feed intake or cow activity. However, 
Table 1. Serum NEFA concentrations in 37 dairy cows (from 3 herds) in the week before expected calving sampled at different times in relation to first feeding of TMR

\begin{tabular}{|c|c|c|c|c|c|c|}
\hline \multirow[b]{2}{*}{ Time of sampling relative to first feeding } & \multicolumn{4}{|c|}{ Fatty acids $(\mathrm{mmol} / \mathrm{L})$} & \multicolumn{2}{|c|}{$\begin{array}{c}\text { Cows with fatty acids } \\
\geq 0.4 \mathrm{mmol} / \mathrm{L}\end{array}$} \\
\hline & Mean $^{1}$ & $\mathrm{SE}$ & Minimum & Maximum & $\mathrm{n}$ & $\%$ \\
\hline $4 \mathrm{~h}$ & $0.18^{\mathrm{b}}$ & 0.04 & 0.10 & 1.00 & $6 / 37$ & $16^{\mathrm{y}}$ \\
\hline $10 \mathrm{~h}$ & $0.22^{\mathrm{ab}}$ & 0.04 & 0.10 & 1.40 & $6 / 37$ & $16^{\mathrm{y}}$ \\
\hline
\end{tabular}

${ }^{\mathrm{a}, \mathrm{b}}$ Values within a column with different superscripts differ significantly $(P<0.05)$.

${ }^{\mathrm{x}, \mathrm{y}}$ Proportions with different superscripts differ $(P=0.10$; pair-wise chi-square).

${ }^{1}$ Back-transformed values.

to our knowledge, no reports exist on variations of the proportions of dairy cows with increased concentrations of NEFA and BHBA at different sampling times relative to the time of feeding TMR in the peripartum period, which is commonly the time frame of interest. The objective of this study was to determine the variation in NEFA and BHBA in serum in relation to the time of first feeding for their use as indicators of energy status in peripartum dairy cows.

High producing Holstein dairy cows from 3 commercial dairy herds in the area of Guelph, Ontario, Canada, were included in this study. In total, 37 cows in the last week before calving and 47 cows in the week following parturition were used. Cows were fed a TMR based on alfalfa haylage, corn silage, and corn and soy products, offered once or twice per day. Ten-milliliter blood samples were taken from the coccygeal vein in tubes containing no preservatives (Vacutainer, Becton Dickinson, Franklin Lakes, NJ) $1 \mathrm{~h}$ before $(-1 \mathrm{~h})$ the first feed ration of the day was offered. Sampling was repeated at $4 \mathrm{~h}$ and $10 \mathrm{~h}$ after the TMR was delivered. Between 30 and 60 min after sampling, tubes were centrifuged for $10 \mathrm{~min}$ at $1,300 \times g$ and the serum was harvested and kept frozen at $-20^{\circ} \mathrm{C}$ until analysis. Samples were submitted to the Animal Health Laboratory, University of Guelph, for analysis. Serum samples were semiquantitatively evaluated by the technicians in the laboratory for hemolysis after thawing using a scale of negative, $1+, 2+, 3+$, and $4+$. Technicians in the laboratory were blinded to the identity of the sera and time of sampling.

In the samples from the precalving period and the postcalving period, NEFA (Randox Laboratories Ltd., Antrion, UK) and BHBA (Ranbut, Randox Laboratories Ltd.), respectively, were determined using colorimetric spectrophotometric methods on a Hitachi 911 chemistry analyzer (Roche, Tokyo, Japan). The interassay coefficients of variation of the fatty acid and BHBA assays were 4.76 and $1.62 \%$, respectively.
The values of NEFA and BHBA were logarithmically transformed to achieve normal distribution for each analyte (NEFA in prepartum cows and BHBA in postpartum cows). Mixed linear regression models [PROC MIXED in SAS (SAS Institute Inc., Cary, $\mathrm{NC}$ )], accounting for the fixed effect of herd, a random effect of cow, and repeated measures on each cow with compound symmetry covariance structure, were used for each analyte to compare means at each time of sampling. Values of NEFA $\geq 0.4 \mathrm{mmol} / \mathrm{L}$ in the precalving samples, based on the results from a previous study (Quiroz-Rocha et al., 2009), and BHBA $\geq 1,400$ $\mathrm{mmol} / \mathrm{L}$ in the postcalving samples, as recommended by Duffield (2000), were considered thresholds for identifying a poor adaptive response to NEB (high NEFA or high BHBA). The proportions of animals with high NEFA or high BHBA at the different sampling times were compared with chi-square statistics.

Three samples from the precalving period $10 \mathrm{~h}$ after first feeding and 3 samples from the postcalving period $4 \mathrm{~h}$ after first feeding had a score of $1+$ hemolysis, but this was considered too mild to interfere with the results; therefore, the results were not excluded (Jacobs et al., 1992). All other samples were negative for hemolysis.

In the samples from cows in the precalving period, back-transformed least squares means values of NEFA were $0.26,0.18$, and $0.22 \mathrm{mmol} / \mathrm{L}$ at $-1,4$, and $10 \mathrm{~h}$, respectively (Table 1). A significant difference was observed between $-1 \mathrm{~h}$ and $4 \mathrm{~h}(P<0.01)$ but not between $-1 \mathrm{~h}$ and $10 \mathrm{~h}(P=0.07)$ or $4 \mathrm{~h}$ and $10 \mathrm{~h}$ $(P=0.07)$. When using $\geq 0.4 \mathrm{mmol} / \mathrm{L}$ as a cut point for NEFA, the group sampled $1 \mathrm{~h}$ before feeding had a higher prevalence of high NEFA $(12 / 37,32 \%)$ compared with the other times $(6 / 37,16 \%$ at both 4 and $10 \mathrm{~h} ; P=0.10)$.

In the samples from postcalving cows, the backtransformed least squares means for BHBA were 837, 772 , and $925 \mu \mathrm{mol} / \mathrm{L}$ at $-1,4$, and $10 \mathrm{~h}$, respectively 
Table 2. Serum BHBA concentrations in 47 dairy cows (from 3 herds) in the first week after calving sampled at different times in relation to first feeding of TMR

\begin{tabular}{|c|c|c|c|c|c|c|}
\hline \multirow[b]{2}{*}{ Time of sampling relative to first feeding } & \multicolumn{4}{|c|}{$\mathrm{BHBA}(\mu \mathrm{mol} / \mathrm{L})$} & \multicolumn{2}{|c|}{$\begin{array}{c}\text { Cows with BHBA } \\
\geq 1,400 \mu \mathrm{mol} / \mathrm{L}\end{array}$} \\
\hline & Mean $^{1}$ & $\mathrm{SE}$ & Minimum & Maximum & $\mathrm{n}$ & $\%$ \\
\hline $4 \mathrm{~h}$ & $772^{\mathrm{a}}$ & 128 & 140 & 5,473 & $5 / 47$ & 10.6 \\
\hline $10 \mathrm{~h}$ & $925^{\mathrm{b}}$ & 111 & 397 & 4,755 & $6 / 47$ & 12.8 \\
\hline
\end{tabular}

${ }^{\mathrm{a}, \mathrm{b}}$ Values within a column with different superscripts differ significantly $(P<0.05)$.

${ }^{1}$ Back-transformed values.

(Table 2). The difference between $4 \mathrm{~h}$ and $10 \mathrm{~h}$ was statistically significant $(P<0.01)$. The means at $-1 \mathrm{~h}$ and $4 \mathrm{~h}(P=0.14)$ and at $-1 \mathrm{~h}$ and $10 \mathrm{~h}(P=0.08)$ were not different. The proportions of high BHBA $(\geq 1,400$ $\mu \mathrm{mol} / \mathrm{L})$ at each time were $8.5,10.6$, and $12.8 \%$, which were not significantly different $(P=0.79)$.

Negative energy balance occurs in dairy cows when their requirements for energy are the highest, and this is caused in large part by the reduction in DMI around calving (Grummer et al., 2004). This occurs as well when diets are not offered in appropriate amounts or access to feed is inadequate. Important advances have been made in recognizing the relationship that exists between several adverse outcomes and a poor adaptive response to NEB (Geishauser and Leslie, 2000; Busato et al., 2002; Oetzel, 2004). Serum NEFA and BHBA concentrations are currently among the most practical metabolites for monitoring NEB as well as for predicting postpartum health-impairing outcomes, both at the individual and the herd level (Herdt, 2000; Oetzel, 2004; LeBlanc et al., 2005). For example, LeBlanc et al. (2005) documented a 3.6 times higher risk for LDA when the precalving fatty acid concentrations were $\geq 0.5 \mathrm{mmol} / \mathrm{L}$ and 8 times greater odds of LDA if BHBA concentrations were $\geq 1,200 \mu \mathrm{mol} / \mathrm{L}$ in the first week postpartum.

Xing et al. (1991) identified higher postprandial NEFA concentrations in heifers receiving $75 \%$ of the maintenance energy requirement compared with heifers receiving $125 \%$ of the maintenance energy requirement, being more evident in cows with high breeding index compared with those with low breeding index, showing a relation between energy intake and circulating NEFA. In the present study, the herds were offered similar diets based on alfalfa haylage, corn silage, and corn and soy products. Mashek et al. (2001) observed diurnal variations in both BHBA and NEFA in an experiment using a hyperinsulinemic-euglycemic clamp in earlyand mid-lactation dairy cows. Nonesterified fatty acids varied according to time of feeding as these metabolites varied in the present study. Also, NEFA markedly in- creased in early-lactation cows when insulin decreased. This increase in circulating NEFA concentration was interpreted as a signal of the beginning of NEB. In this same trial, there was no effect of treatment on BHBA concentration (Mashek et al., 2001). These researchers concluded that variations in these metabolites occur with time, and possibly in relation to feed intake.

Eicher et al. (1999) observed a decrease in plasma NEFA concentrations in dairy cows between 40 and 230 DIM, but within day higher values were observed 10 $\mathrm{h}$ after first feeding; they did not take samples before feeding. Others (Nielsen et al., 2003; Brickner et al., 2007) have documented effects of diet or handling of cows on concentrations of NEFA and BHBA.

In the present study, at the $-1 \mathrm{~h}$ sampling, there was a $32 \%$ prevalence of high NEFA $(\geq 0.4 \mathrm{mmol} / \mathrm{L})$ compared with $16 \%$ prevalence in the samples taken after feed delivery. This higher concentration of serum NEFA may indicate greater lipolysis in the hours when feed intake is reduced (Kunz et al., 1985, Grummer, 1993). In the present study, feed was first delivered around the time of morning milking (approximately 0500 to 0700 h). Others (e.g., DeVries et al., 2003) have shown that feed intake is very low between midnight and first feeding. This might be exacerbated if feed is not available or accessible $24 \mathrm{~h} / \mathrm{d}$.

Within a herd, whether for investigation of problems or for routine monitoring, it is important to sample at a consistent time relative to feeding to avoid confounding and misinterpretation of results, especially when interpreting serial samples.

When sampling cows to monitor elements of energy metabolism in the prepartum period, there was twice the probability of detecting animals with NEFA values $\geq 0.4 \mathrm{mmol} / \mathrm{L}$ if they were sampled $1 \mathrm{~h}$ before the first feed delivery compared with sampling the same cows 4 or $10 \mathrm{~h}$ after feeding. It is necessary to take samples at a consistent time relative to feeding within a given herd in order to not misclassify cows. When using BHBA to identify subclinical ketosis in postparturient cows at the cut-point of $1,400 \mu \mathrm{mol} / \mathrm{L}$, there was no difference 
in the time when the sample was taken in relation to the first feeding.

\section{ACKNOWLEDGMENTS}

This study was funded by the Dairy Farmers of Ontario (Mississauga, Ontario, Canada) and the Ontario Ministry of Agriculture and Food (Guelph, Ontario, Canada). We thank William Sears (Department of Population Medicine, University of Guelph, Guelph, Ontario, Canada) for his advice and guidance with the statistical analysis. G. Quiroz-Rocha thanks Dirección General de Apoyo al Personal Académico-Universidad Nacional Autónoma de México (DGAPA-UNAM; México, DF) for sponsoring his graduate studies, including the present study.

\section{REFERENCES}

Abdelkader, S. V., and E. Ropstad. 1989. Diurnal and individual variations in bile acids in the plasma of normal dairy cows. Acta Vet. Scand. 30:221-228.

Brickner, A. E., R. R Rastani, and R. R. Grummer. 2007. Technical note: Effect of sampling protocol on plasma nonesterified fatty acid concentration in dairy cows. J. Dairy Sci. 90:2219-2222.

Busato, A., D. Faissler, U. Küpfer, and J. W. Blum. 2002. Body condition scores in dairy cows: Associations with metabolic and endocrine changes in healthy dairy cows. J. Vet. Med. A 49:455460.

Cameron, R. E. B., P. B. Dyk, T. H. Herdt, J. B. Kaneene, R. Miller, H. F. Bucholtz, J. S. Liesman, M. J. Vandehaar, and R. S. Emery. 1998. Dry cow diet, management, and energy balance as risk factors for displaced abomasum in high producing dairy herds. J. Dairy Sci. 81:132-139.

Christensen, J. O., R. R. Grummer, F. E. Rasmussen, and S. J. Bertics. 1997. Effect of method of delivery of propylene glycol on plasma metabolites of feed-restricted cattle. J. Dairy Sci. 80:563-568.

Coggins, C. R. E., and A. C. Field. 1978. Changes in plasma concentrations of glucose, free fatty acids, ketone bodies, thyroxine and insulin of lactating beef cows in relation to time of feeding and energy status. Pages 41-47 in BSAP Occasional Publication. British Society of Animal Production, London, UK

de Boer, G., A. Trenkle, and J.W. Young. 1985. Glucagon, insulin, growth hormone, and some blood metabolites during energy restriction ketonemia of lactating cows. J. Dairy Sci. 68:326337.

DeVries, T. J., M. A. G. von Keyserlingk, and K. A. Beauchemin. 2003. Short communication: Diurnal feeding pattern of lactating dairy cows. J. Dairy Sci. 86:4079-4082.

Doepel, L., H. Lapierre, and J. J. Kennelly. 2002. Peripartum performance and metabolism of dairy cows in response to prepartum energy and protein intake. J. Dairy Sci. 85:2315-2334.

Duffield, T. 2000. Subclinical ketosis in lactating dairy cattle. Vet. Clin. North Am. Food Anim. Pract. 16:231-253.

Duffield, T. 2004. Monitoring strategies for metabolic disease in transition dairy cows. Pages $34-35$ in Le Medicin Veterinaire du Quebec. Proc. 23th World Buiatrics Congress, Quebec, Canada.
Eicher, R., A. Liesegang, E. Bouchard, and A. Tremblay. 1999. Effect of cow-specific factors and feeding frequency of concentrate on diurnal variations of blood metabolites in dairy cows. Am. J. Vet. Res. 60:1493-1499.

Geishauser, T., and K. Leslie. 2000. Metabolic aspects in the etiology of displaced abomasum. Vet. Clin. North Am. Food Anim. Pract. $16: 255-265$

Grummer, R. R. 1993. Etiology of lipid-related metabolic disorders in periparturient dairy cows. J. Dairy Sci. 76:3882-3896.

Grummer, R. R., D. G. Mashek, and A. Hayirli. 2004. Dry matter intake and energy balance in the transition period. Vet. Clin. North Am. Food Anim. Pract. 20:447-470.

Herdt, T. H. 2000. Variability characteristics and test selection in herd-level nutritional and metabolic profile testing. Vet. Clin. North Am. Food Anim. Pract. 16:387-403.

Jacobs, R. M., J. H. Lumsden, and E. Grift. 1992. Effects of bilirubinemia, hemolysis, and lipemia on clinical chemistry analytes in bovine, canine, equine, and feline sera. Can. Vet. J. 33:605-608.

Kaneene, J. B., R. Miller, T. H. Herdt, and J. C. Gardiner. 1997. The association of serum nonesterified fatty acids and cholesterol, management and feeding practices with peripartum disease in dairy cows. Prev. Vet. Med. 31:59-72.

Kunz, P. L., J. W. Blum, I. C. Hart, H. Bickel, and J. Landis. 1985. Effects of different energy intakes before and after calving on food intake, performance and blood hormones and metabolites in dairy cows. Anim. Prod. 40:219-231.

LeBlanc, S. J., K. E. Leslie, and T. F. Duffield. 2005. Metabolic predictors of displaced abomasum in dairy cattle. J. Dairy Sci. $88: 159-170$.

Manston, R., G. J. Rowlands, W. Little, and K. A. Collis. 1981. Variability of the blood composition of dairy cows in relation to time of day. J. Agric. Sci. 96:593-598.

Mashek, D. G., K. L. Ingvartsen, J. B. Andersen, M. Vestergaard, and T. Larsen. 2001. Effects of a four-day hyperinsulinemiceuglycemic clamp in early and mid-lactation dairy cows on plasma concentrations of metabolites, hormones, and binding proteins. Domest. Anim. Endocrinol. 21:169-185.

Nielsen, N. I., K. L. Ingvartsen, and T. Larsen. 2003. Diurnal variation and the effect of feed restriction on plasma and milk metabolites in TMR-fed dairy cows. J. Vet. Med. A 50:88-97.

Oetzel, G. R. 2004. Monitoring and testing dairy herds for metabolic disease. Vet. Clin. North Am. Food Anim. Pract. 20:651-674.

Pushpakumara, P. G. A., N. H. Gardner, C. K. Reynolds, D. E. Beever, and D. C. Wathes. 2003. Relationships between transition period diet, metabolic parameters and fertility in lactating dairy cows. Theriogenology 60:1165-1185.

Quiroz-Rocha, G. F., S. LeBlanc, T. Duffield, D. Wood, K. E. Leslie, and R. M. Jacobs. 2009. Evaluation of prepartum serum cholesterol and fatty acids concentrations as predictors of postpartum retention of the placenta in dairy cows. J. Am. Vet. Med. Assoc. 234:790-793.

Smith, B. I., and C. A. Risco. 2005. Management of periparturient disorders in dairy cattle. Vet. Clin. North Am. Food Anim. Pract. 21:503-521.

Xing, G. Q., D. D. S. Mackenzie, and S. N. McCutcheon. 1991. Diurnal variation in plasma metabolite and hormone concentrations and response to metabolic challenges in high breeding index and low breeding index Friesian heifers fed at two allowances. N.Z. J. Agric. Res. 34:295-304. 